\title{
Beneficial medicinal plants in digestive system disorders (part 2): plant based review
}

\author{
Prof Dr Ali Esmail Al-Snafi \\ Department of Pharmacology, College of Medicine, Thi qar University, Iraq
}

\begin{abstract}
Many plants possessed beneficial effects in gastric diseases especially peptic ulcer diseases and in intestinal disease especially diarrhea and ulcerative colitis, these plants included: Agrimonia eupatoria, Ailanthus altissima, Alhagi maurorum, Aloe vera, Alpinia galangal, Ammannia baccifera, Anchusa italic and Anchusa strigosa, Anethum graveolens, Apium graveolens, Asparagus officinali, Asphodelus fistulosus, Avena sativa, Bacopa monnieri, Bauhinia variegate, Bellis perennis, Benincasa hispida, Bidens tripartite, Brassica nigra, Bryophyllum calycinum, Caesalpinia bonducella, Calendula officinalis, Calotropis procera, Canna indica, Capsicum annuum and Capsicum frutescens, Carthamus tinctorius, Carum carvi and Casuarina equisetifolia. This review was designed to highlight the pharmacological effects of medicinal plants in gastrointestinal diseases as a second part of our previous review.
\end{abstract}

Keywords: herbs, plants, gastrointestinal, peptic ulcer, diarrhea, ulcerative colitis

\section{INTRODUCTION}

In the last few decades there has been an exponential growth in the field of herbal medicine. It is getting popularized in developing and developed countries owing to its natural origin and lesser side effects. Digestive system disorders have a substantial effect on worldwide morbidity and mortality rates. Many plants possessed beneficial effects on gastrointestinal disorders and can be used as alternatives in stomach diseases especially peptic ulcer disease and in intestinal disease especially diarrhea and ulcerative colitis, these plants included: included: Agrimonia eupatoria [1], Ailanthus altissima [2], Alhagi maurorum [3], Aloe vera [4], Alpinia galangal [5], Ammannia baccifera [6], Anchusa italic and Anchusa strigosa [7], Anethum graveolens [8], Apium graveolens [9], Asparagus officinali [10], Asphodelus fistulosus [11], Avena sativa [12], Bacopa monnieri [13], Bauhinia variegate [14], Bellis perennis [15], Benincasa hispida [16], Bidens tripartite [17], Brassica nigra [18], Bryophyllum calycinum [19], Caesalpinia bonducella [11, 20], Calendula officinalis [21], Calotropis procera [22], Canna indica [23], Capsicum annuum and Capsicum frutescens [24], Carthamus tinctorius [25], Carum carvi [26] and Casuarina equisetifolia [27]. This review was designed to highlight the pharmacological effects of medicinal plants in gastrointestinal diseases as a second part of our previous reviews[11,28].

\section{Plants beneficial in gastrointestinal diseases: \\ I- Effect on stomach: \\ Citrullus colocynthis}

The Citrullus colocynthis seed methanolic extract was evaluated for anti-ulcerogenic activity by pyloric ligation induced ulcers model in Wistar albino rats. Citrullus colocynthis (200 mg/kg) showed maximum inhibition of gastric volume $1.68 \pm 0.18$, free acid $39.86 \pm 3.86$ and total acidity $61.23 \pm 1.87$ at dose of $200 \mathrm{mg} / \mathrm{kg}$. The maximum percentage inhibition of ulcerogenicity by the extract in pyloric ligation model was $71.57 \%$ at a dose of $200 \mathrm{mg} / \mathrm{kg}$ [29-30].

\section{Citrus species}

The antiulcer activity of aqueous extract of the fruits of Citrus medica was evaluated against ethanolinduced ulcers in rats. The rats were pretreated with the extract at two doses $(250$ and $500 \mathrm{mg} / \mathrm{kg}$ po $)$ and the antiulcer effect was compared with that of ranitidine $(20 \mathrm{mg} / \mathrm{kg} \mathrm{po})$. The extract of both doses showed a significant reduction in ulcer formation. Histopathological sections showed significant decrease in mucosal ulceration, inflammatory mucosal changes and submucosal edema compared to ethanol treated group and the ranitidine group. It was concluded that, the fruits of Citrus medica possesses significant antiulcer activity against ethanol-induced ulcers in rats and the antiulcer activity could be due to the presence of flavonoids as these compounds have well documented antiulcer activity [31]. 


\section{Clitoria ternatea}

The antiulcer potential of aqueous and ethanolic extracts of Clitoria ternatea was evaluated in different experimentally induced ulcer models in rats. Ethanolic extract (200 and $400 \mathrm{mg} / \mathrm{kg}$ ) and aqueous extract $(200$ and $400 \mathrm{mg} / \mathrm{kg}$ ) of whole plant were examined in pylorus ligation and indomethacin induced gastric ulcer in rats. Various parameters like volume of gastric acid secretion, $\mathrm{pH}$, total acidity, ulcer index and antioxidant parameters were determined and compared between extracts, standard and vehicle control group following ulcer induction. Among different dose of alcoholic extract, high dose showed significant antiulcer activity in pylorus ligation and indomethacin induced ulceration [32-33].

\section{Cordia myxa}

The protective effects of Cordia myxa fruit extract (CME) was investigated against indomethacininduced gastric ulcer in rats. Gastric ulceration was induced by a single intraperitoneal injection of indomethacin $(30 \mathrm{mg} / \mathrm{kg}$ bw). CME was administered orally at a dose of $125 \mathrm{mg} / \mathrm{kg} \mathrm{bw}$, while ranitidine (RAN), which used as a reference drug, was given at a dose of $50 \mathrm{mg} / \mathrm{kg}$ bw, two weeks prior to indomethacin injection. Pretreatment with CME produced significant reduction in gastric mucosal lesions, malondialdehyde (MDA), and serum tumor necrosis factor (TNF $\alpha$ ) associated with significant increase in gastric juice mucin content and gastric mucosal catalase (CAT), nitric oxide (NO), and prostaglandin E2 (PGE2) levels. A similar increase in mucin content, NO and PGE2 was not observed with RAN although it generated a preventive index of $75.9 \%$. RAN significantly increased $\mathrm{pH}$ value and decreased pepcin activity, and gastric juice free and total acidity. Histological studies of stomach mucosa confirmed these results. Stomach of rats administrated with RAN showed leukocytic infiltration in submucosal layer. Meanwhile, stomach of rats administrated CME either alone or with RAN showed no histopathological changes. CME can protect indometacin-induced gastric ulceration due to its antioxidative and mucin enhancing properties. The protection afforded by co-administration of CME and RAN was found to be better than that of RAN alone [34-35].

\section{Coriandrum sativum}

The effect of coriander pretreatment on gastric mucosal injuries caused by $\mathrm{NaCl}, \mathrm{NaOH}$, ethanol, indomethacin and pylorus ligation accumulated gastric acid secretions was investigated in rats. Pretreatment at oral doses of 250 and $500 \mathrm{mg} / \mathrm{kg}$, was found to provide a dose-dependent protection against the (i) ulcerogenic effects of different necrotizing agents; (ii) ethanol-induced histopathological lesions; (iii) pylorus ligated accumulation of gastric acid secretions and ethanol related decrease of nonprotein sulfhydryl groups (NP-SH). Results of gastric mucus and indomethacin-induced ulcers demonstrated that the gastro protective activity of Coriander might not be mediated by gastric mucus and/or endogenous stimulation of prostaglandins. The authors suggested that the protective effect against ethanol-induced damage of the gastric tissue might be related to the free-radical scavenging property of different antioxidant constituents (linanool, flavonoids, coumarins, catechins, terpenes and polyphenolic compounds) present in coriander. The inhibition of ulcers might be due to formation of a protective layer of either one or more of these compounds by hydrophobic interactions [36].

The effect of selected indigenous medicinal plants of Pakistan was evaluated on the secretion of interleukin-8 (IL-8) and generation of reactive oxygen species (ROS) to rationalize their medicinal use and to examine the anti-inflammatory and cytoprotective effects in gastric epithelial cells. AGS cells and clinically isolated Helicobacter pylori strain (193C) were employed for co-culture experiments. Coriandrum sativum, demonstrated significant suppression of ROS from Helicobacter pylori-infected cells $(\mathrm{p}<0.01)$ [37].

\section{Crocus sativus}

An aqueous suspension of saffron was subjected to evaluate its gastric antiulcer activity induced by pylorus ligation (Shay rats), indomethacin and various necrotizing agents including (80\% ethanol, $0.2 \mathrm{M} \mathrm{NaOH}$ and $25 \% \mathrm{NaCl}$ ) in rats. Gastric wall mucus and non-protein sulfhydryl contents were estimated in rats. Histopathological assessment of rat stomach was also carried out. The saffron aqueous suspension at doses (250 and $500 \mathrm{mg} / \mathrm{kg}$ ) decreased gastric secretion and ulcer index in Shay rats and indomethacin treated groups. Gastric wall mucus was enhanced. A large margin of safety was observed in animals after acute and chronic treatment [38].

The effects of an ethanol and aqueous extract of saffron Crocus sativus and its constituents safranal and crocin was investigated on stress-induced reduction in food intake, weight gain and anorexic time in mice. Male albino mice were irregularly exposed to a trial of electroshock stress for 7 days. Then, the anorexic time as well as the animal's food intake and weight were recorded. Intraperitoneal administration of the aqueous but not the ethanol extract $(10,50$ and $100 \mathrm{mg} / \mathrm{kg})$ significantly reduced the anorexic time. The results were similar for crocin $(1,5$ and $10 \mathrm{mg} / \mathrm{kg}$; ip). In addition, a reduction in weight gain was observed in the controls as well as in the groups that received alcohol extract or safranal. The plasma corticosterone level did not increase in the 
aqueous extract and crocin treated animals. The authors concluded that the saffron aqueous extract and its constituent crocin reduce side effects of electroshock stress in mice [39].

The beneficial effect of saffron (Crocus sativus) aqueous extract (SAE) on the 1-Methyl -3- nitro -1nitrosoguanidine (MNNG)-induced gastric cancer was investigated in rats. Different concentrations of SAE were administered to rats. After sacrificing, the stomach tissue was investigated by both pathologist and flow cytometry, and several biochemical parameters were determined in the plasma (or serum) and stomach of rats. Pathologic data indicated the induction of cancer at different stages from hyperplasia to adenoma in rats was inhibited by SAE administration; $20 \%$ of cancerous rats treated with higher doses of SAE was completely became normal at the end of experiment and there was no rat with adenoma in the SAE treated groups [40].

\section{Cuminum cyminum}

The stomach of pentobarbitone-anesthetized rats was perfused at $0.15 \mathrm{ml} / \mathrm{min}$ with aqueous extracts of cumin or acetylcholine ( $1 \mathrm{microgram} / \mathrm{ml}$ or $10 \mathrm{micrograms} / \mathrm{ml}$ solutions, in $40 \mathrm{~min}$ blocks, twice in each experiment bracketed by saline perfusions. The acid content in the samples was estimated by titration with $0.1 \mathrm{~N}$ $\mathrm{NaOH}$ with phenolphthalein as indicator. Cumin increased stomach acid secretion from 0.08 to 0.02 . (p< $0.05)$ [41-42].

The antiulcer activity of the aqueous extracts of leaves of dried fruits of cumin against the diclofenac sodium induced stomach ulceration has been studied in rats in comparison with omeprazole. Cumin extract accelerated the healing process to different extents. Healing activity of the aqueous extracts of combination of piper betel and cumin was found to be beter than healing activity of aqueous extracts of cumin and piper betel alone. Aqueous extract also enhance gastric mucin protection and regeneration [42-43].

\section{Cynodon dactylon}

The effect of 50\% ethanolic extract of Cynodon dactylon Pers was evaluated in gastro-ulcerogenic potential of indomethacin. $50 \%$ ethanolic extract of Cynodon dactylon was administered in the dose of 300 and $600 \mathrm{mg} / \mathrm{kg}$ orally 30 minutes prior to ulcer induction in male Sprague-Dawley rats by oral administration of indomethacin. Famotidine was used as a reference standard drug. The antiulcer activity was assessed by determining and comparing the ulcer index in the test drug group with that of the vehicle and standard groups. Both the doses, 300 and $600 \mathrm{mg} / \mathrm{kg}$ of test drug showed a protective effect on indomethacin- induced ulcers with $56.74 \%$ and $79.61 \%$ ulcer inhibition rate, respectively [44].

The gastro-protective effect of Cynodon dactylon was studied in alcohol and indomethacin induced gastric mucosal damage. The control group received only ulcerogen, whereas the standard control group and test compound groups were pretreated with ranitidine $(25 \mathrm{mg} / \mathrm{kg}$ ) and Cynodon dactylon (300 and $450 \mathrm{mg} / \mathrm{kg}$ of the plant juice powder, intragastrically) respectively, before exposure to ulcerogen. 4 hours after exposure to ulcerogen the rats were sacrificed, stomachs were dissected out and opened. The total number of ulcers, size of each ulcer was noted and ulcer index was calculated.. In alcohol model the rats pretreated with Cynodon dactylon showed significant protection as compared to control and ranitidine pretreated groups. However in indomethacin model the rats pretreated with ranitidine gave better protection [45].

The extract of Cynodon dactylon was investigated for its anti- ulcer activity against pylorus ligation, aspirin induced and ethanol induced gastric ulcer in rats at 100, 200, $300 \mathrm{mg} / \mathrm{kg} \mathrm{bw}$. A significant reduction $(\mathrm{p}<0.01)$ in ulcer index was seen in Cynodon dactylon extract treated rats of pylorus ligation, aspirin induced and ethanol induced gastric ulcer models. The gastroprotective effect was further confirmed by histopathological examination of rat stomach [46].

Alcoholic extract of Cynodon dactylon was evaluated at 200, 400, and $600 \mathrm{mg} / \mathrm{kg}$ bw, orally for pylorus ligated and indomethacin induced gastric ulcer models in albino rats. Alcoholic extracts at 400 and 600 $\mathrm{mg} / \mathrm{kg}$ showed significant ( $\mathrm{p}>0.001)$ antiulcer activity, comparable to the standard drug ranitidine [47].

\section{Cyperus rotuntdus}

The antiulcer activity of crude extract of Cyperus rotundus was studied in rats at a dose of $(300 \mathrm{mg} / \mathrm{kg}$ and $500 \mathrm{mg} / \mathrm{kg}$ ). Ulcer was induced in rats by aspirin $300 \mathrm{mg} / \mathrm{kg}$. Crude extract induced significant antiulcer effect [48].

The protective effects of Cyperus rotundus on gastric mucosal damage induced by ischemia and reperfusion was studied in rats. Ischemia/reperfusion model was designed as $30 \mathrm{~min}$ ischemia followed by 60 min reperfusion by clamping the celiac artery. The Cyperus rotundus extracts were given at the doses of 100 or $200 \mathrm{mg} / \mathrm{kg}$ to prevent postischemic gastric mucosal injury. Antioxidant enzymes activity such as malondialdehyde and glutathione-peroxidase were measured in the gastric tissue. Histopathological sections were examined for ischemic injury. The mean ulcer index of rats treated with 200 and $100 \mathrm{mg} / \mathrm{kg}$ Cyperus rotundus were significantly lower $(\mathrm{p}<0.05)$ than that of control rats. The activities of antioxidant enzymes were significantly enhanced $(\mathrm{p}<0.05)$ by treatment with Cyperus rotundus extracts [49]. 
Decoctions of Cyperus rotundus rhizome were given orally $(1.25,2.5,4.0 \mathrm{~g}$ crude drug $/ \mathrm{kg})$ to rats 30 min before ethanol showed gastric ulcer inhibitory effect in a dose dependent manner [50]. The ulcerpreventive role of Cyperus rotundus was studied in rats treated with non-steroidal anti-inflammatory drugs. Oral administration of different doses of Cyperus rotundus rhizome methanolic extract ( 250 and $500 \mathrm{mg} / \mathrm{kg}$ ) significantly inhibited aspirin-induced gastric ulceration in animals in a dose-dependent manner $(49.32 \%$ and $53.15 \%$, respectively), which was also comparable with the standard gastric ulcer drug ranitidine. Administration of Cyperus rotundus rhizome methanolic extract also significantly increased the activity of superoxide dismutase, cellular glutathione and glutathione peroxidase, and inhibited the lipid peroxidation in the gastric mucosa of ulcerated animals in a dose-dependent manner [51].

\section{II-Effect on intestine: Cicer arietinum}

The antidiarrhoeal activity of the hydroalcoholic extract of Cicer arietinum roots and its acetone and methanol fraction was studied based on their effect on Castor oil induced diarrhea in mice. The results showed that the highest reduction in diarrhoea was observed in hydroalcoholic extract (24.63\%), while Loperamide (5 $\mathrm{mg} / \mathrm{kg}$ ) inhibited the castor oil induced diarrhoea by $75.37 \%$ [52].

\section{Convolvulus arvensis}

The antidiarrhoeal activity of the aerial parts methyl alcohol extracts of Convolvulus arvensis (200 and $400 \mathrm{mg} / \mathrm{kg}$ ) was investigated in castor oil-induced diarrhea in rats, and on the motility of isolated rabbit's duodenum. Oral administration of methanol extract of Convolvulus arvensis in a dose of $400 \mathrm{mg} / \mathrm{kg}$ produced no significant effect on the fecal discharge in rats. On the other hand Convolvulus arvensis induced a dosedependent $(0.8-3.2 \mathrm{mg} / \mathrm{ml})$ inhibitory effect on the isolated rabbit duodenum. This effect was slow in onset at small doses. Calcium chloride $(25 \mu \mathrm{g} / \mathrm{ml})$ added to the calcium-free solution reversed the contractile response of the rabbit's duodenum. Acetylcholine and small dose of nicotine reversed the contractile response of the tissues. Moreover, the extract produced its effect after blocking by propranolol or by yohimbine [53-54]. However, oral administration of $1 / 10 \mathrm{LD}_{50}$ of alcoholic extract of Convolvulus arvensis blocked diarrhea, enteropooling and intestinal transits induced by castor oil in rats, comparable to that of atropine [54-55].

\section{Convolvulus scammonia}

Scammony, gum-resin which obtained from the root of Convolvulus scammonia was used as a drastic purgative in 1 to 3 -grain doses. In large doses it acts as a strong gastro-intestinal irritant, and may cause death, if administered to weak, debilitated persons $[54,56]$.

The active principle of Scammony (Convolvulus scammonia) was inert until it has passed from the stomach into the duodenum, where it meets the bile, a chemical reaction occurring between it and the taurocholate and glycocholate of sodium, whereby it was converted into a powerful purgative [54, 57].

\section{Coriandrum sativum}

The efficacy of Coriandrum sativum on gut modulation was studied, coriander crude extract was evaluated through in vitro and in vivo techniques. Coriander crude extract caused atropine sensitive stimulatory effect in isolated guinea-pig ileum and rabbit jejunum preparations $(0.1-10 \mathrm{mg} / \mathrm{ml})$. It exhibited relaxation against both spontaneous and high $\mathrm{K}^{+}(80 \mathrm{mM})$-induced contractions as well as shifted the $\mathrm{Ca}^{2+}$ concentrationresponse curves to right, similar to that caused by verapamil. Bioassay-directed fractionation revealed the separation of spasmogenic and spasmolytic components in the aqueous and organic fractions, respectively [58].

\section{Crotalaria juncea}

The anti-diarrhoeal effects of methanolic extract of leaves of Crotalaria juncea (MECJ) was studied against castor oil-induced diarrhoea model and small intestine transit model in rats. The number of droppings and the distance traveled by charcoal in intestine were measured. MECJ at the doses of 200 and $400 \mathrm{mg} / \mathrm{kg}$ significantly inhibited $(\mathrm{P}<0.001)$ the castor oil induced charcoal meal transit. The MECJ showed marked reduction in the frequency of bowel motion as well as a modest reduction in intestinal transit [59-60].

\section{Cuminum cyminum}

The effect of aqueous extract of Cuminum cyminum seeds (ACCS) was studied against diarrhoea on albino rats. The animals were divided into five groups and the control group was given $2 \%$ acacia suspension, the standard group with loperamide $(3 \mathrm{mg} / \mathrm{kg})$ or atropine sulphate $(5 \mathrm{mg} / \mathrm{kg})$ and three test groups administered orally with 100, 250 and $500 \mathrm{mg} / \mathrm{kg}$ of ACCS. The antidiarrhoeal effect was investigated by castor oil induce diarrhoea model, prostaglandin E2 (PGE2) induced enteropooling model and intestinal transit by charcoal meal test. The ACCS showed significant $(\mathrm{p}<0.001)$ inhibition in frequency of diarrhoea, defecation time delaying, 
secretion of intestinal fluid as well as intestinal propulsion as compared to control. The graded doses of the tested extract showed dose dependent protection against diarrhea [61].

\section{Cydonia oblonga}

The pharmacological rationalization for the medicinal use of Cydonia oblonga in gut and airways diseases was investigated. Results showed that the crude extract of Cydonia oblonga seeds (Co.Cr) produced atropine sensitive spasmodic effects in isolated ileum of guinea-pig and rabbit jejunum preparations. In rabbit jejunum, Co.Cr also showed relaxant activity at slightly higher concentrations $(0.1-10 \mathrm{mg} / \mathrm{ml})$. When analyzed on rabbit jejunum pre-contracted with $\mathrm{K}^{+}(80 \mathrm{mM})$, the plant extract $(0.003-10 \mathrm{mg} / \mathrm{ml})$ produced relaxation. A rightward shifting of $\mathrm{Ca}^{++}$dose-response curves along with decline in the maximum response was observed after pretreatment with $\mathrm{Co} . \mathrm{Cr}(0.003-0.01 \mathrm{mg} / \mathrm{ml})$, which was similar to the effect of verapamil. The crude extract of Cydonia oblonga seeds (Co.Cr) $(0.01-10 \mathrm{mg} / \mathrm{ml})$ relaxed $\mathrm{CCh}(1 \mu \mathrm{M})$ and $\mathrm{K}^{+}(80 \mathrm{mM})$-induced contractions of isolated rabbit tracheal preparations, similar to the effect produced by verapamil [62].

The effect of quince juice (QJ) and quince hydroalcoholic extract (QHE) on ullcerative colitis (UC) induced by TNBS (trinitrobenzene sulfonic acid) was studied in rats. Rats were grouped and fasted for $36 \mathrm{hr}$ before colitis induction. TNBS was instilled into the colon with a hydroalcoholic carrier and then treated for 5 days starting $6 \mathrm{~h}$ after colitis induction with different doses of QJ $(200,400,800 \mathrm{mg} / \mathrm{kg})$, QHE $(200,500 \& 800$ $\mathrm{mg} / \mathrm{kg}$ ) orally, QJ $(400 \mathrm{mg} / \mathrm{kg}$ ) and QHE (200 and $500 \mathrm{mg} / \mathrm{kg}$ ) intraperitoneally. The colon tissue was removed and tissue damages were scored after macroscopic and histopathologic assessments. The examined doses of QJ and QHE were effective to reduce the extent of UC lesions, only the greatest doses (500 and $800 \mathrm{mg} / \mathrm{kg}$ ) resulted in significant alleviation. Weight/length ratio as an illustrative of tissue inflammation and extravasation was also diminished with quince treatments [63].

Cydonia oblonga fruit preparations reduced the gastrointestinal propulsion and inhibited castor oilinduced diarrhoea in mice [64].

\section{Cynodon dactylon}

The hexane, dichloromethane, ethyl acetate and methanol extracts of Cynodon dactylon whole plant were tested for anti-diarrheal activity on castor oil induced diarrhea, gastro intestinal motility by charcoal meal and entero pooling models in albino rats. Methanol extract exhibited considerable inhibition of castor oil induced diarrhea. Methanol extract also showed a significant decrease in gastrointestinal motility by charcoal meal and decrease in weight of intestinal contents in enteropooling models. The results indicated that the plant possessed good anti- diarrheal activity [65-66].

\section{Cyperus rotuntdus}

An aqueous extract of tubers of Cyperus rotundus (ACR) was tested for its antidiarrhoeal and antispasmodic activity. Antidiarrhoeal effect of ACR was evaluated in castor oil induced diarrhea in mice and antispasmodic effect was evaluated by charcoal meal test in mice at a dose of $125,250,500 \mathrm{mg} / \mathrm{kg}$. The $\%$ inhibition of diarrhoea was $30.36 \%, 37.90 \%, 45.45 \%$ and $92.45 \%$ for ACR $125,250,500 \mathrm{mg} / \mathrm{kg}$ orally and loperamide $2 \mathrm{mg} / \mathrm{kg}$ dose orally respectively. ACR $125,250,500 \mathrm{mg} / \mathrm{kg}$ orally and atropine sulphate $2 \mathrm{mg} / \mathrm{kg}$ dose orally produced $24.35 \%, 31.48 \%, 36.75 \%$ and $55.94 \%$ inhibition of intestinal transit respectively [67$68]$.

The methanol extract of Cyperus rotundus rhizome, given orally at the doses of 250 and $500 \mathrm{mg} / \mathrm{kg}$ bw, showed significant antidiarrhoeal activity in castor oil induced diarrhoea in mice. Among the fractions, tested at $250 \mathrm{mg} / \mathrm{kg}$, the petroleum ether fraction and residual methanol fraction showed antidiarrhoeal activity, the latter being more active as compared to the control. The ethyl acetate fraction did not show any antidiarrhoeal activity [69].

The antidiarrheal activity of the decoction of Cyperus rotundus tubers was studied using representative assays of diarrheal pathogenesis. Antibacterial, antigiardial and antirotaviral activities were studied. Effect on adherence of enteropathogenic Escherichia coli (EPEC) and invasion of enteroinvasive $E$. coli (EIEC) and Shigella flexneri to HEp-2 cells was evaluated as a measure of effect on colonization. Effect on enterotoxins such as enterotoxigenic E. coli (ETEC) heat labile toxin (LT), heat stable toxin (ST) and cholera toxin $(\mathrm{CT})$ was also assessed. The decoction showed antigiardial activity, reduced bacterial adherence to and invasion of HEp-2 cells and affected production of CT and action of LT. The decoction of Cyperus rotundus did not exerted marked antimicrobial activity and it is exerted its antidiarrheal action by mechanisms other than direct killing of the pathogen [70].

The effect of Cyperus rotundus was investigated on adherence and enterotoxin production of 2 groups of E.coli enteropathogenic (EPEC) and enterotoxigenic (ETEC). A decoction of the root bulbs of Cyperus rotundus was prepared by boiling $1 \mathrm{gm}$ of plant material in $16 \mathrm{ml}$ distilled water till the volume was reduced to $4 \mathrm{ml}$. The decoction was then centrifuged at 2500 RPM for 10 minutes and filtered through a 
membrane of $0.22 \mu$ pore size before use. A significant inhibition in labile toxin production was noted at 24 hours, at a 1:2 dilution and at 72 hours at 1:2 and 1:100 dilution. Stable toxin was inhibited at 1:10, 1:100 and 1:1000 dilutions, maximum inhibition seen at 1:1000. An inverse correlation was observed between the stable toxin production and the concentration of the decoction [71].

\section{CONCLUSION}

The review was designed to highlight the gastrointestinal effects of the medicinal plants to open the door for their clinical uses as a result of efficacy and safety. Furthermore, it is of the utmost importance to conduct phytochemical investigations and clinical trials on the most promising species.

\section{REFERENCES}

[1]. Al-Snafi AE. The pharmacological and therapeutic importance of Agrimonia eupatoria- A review. Asian Journal of Pharmaceutical Science and Technology 2015; 5(2): 112-117.

[2]. Al-Snafi AE. The pharmacological importance of Ailanthus altissima- A review. International Journal of Pharmacy Review and Research 2015; 5(2):121-129

[3]. Al-Snafi AE. Alhagi maurorum as a potential medicinal herb: An Overview. International Journal of Pharmacy Review and Research 2015; 5(2):130-136.

[4]. Al-Snafi AE. The pharmacological importance of Aloe vera- A review. International Journal of Phytopharmacy Research 2015; 6(1) : 28-33.

[5]. Al-Snafi AE. The pharmacological activities of Alpinia galangal - A review. International Journal for Pharmaceutical Research Scholars 2014; 3(1-1): 607-614.

[6]. Al-Snafi AE. The chemical constituents and pharmacological effects of Ammannia baccifera - A review. International Journal of Pharmacy 2015; 5(1): 28-32.

[7]. Al-Snafi AE. The pharmacology of Anchusa italica and Anchusa strigosa - A review. International Journal of Pharmacy and Pharmaceutical Sciences 2014; 6(4): 7-10.

[8]. Al-Snafi AE. The pharmacological importance of Anethum graveolens - A review. International Journal of Pharmacy and Pharmaceutical Sciences 2014; 6(4): 11-13.

[9]. Al-Snafi AE. The Pharmacology of Apium graveolens. - A review. International Journal for Pharmaceutical Research Scholars 2014; 3(1-1): 671-677.

[10]. Al-Snafi AE. The pharmacological importance of Asparagus officinalis - A review. Journal of Pharmaceutical Biology 2015; 5(2): 93-98.

[11]. Al-Snafi AE. Therapeutic properties of medicinal plants: a review of their gastro-intestinal effects (part 1). Ind J of Pharm Sci \& Res 2015; 5(4): 220-232.

[12]. Al-Snafi AE. The nutritional and therapeutic importance of Avena sativa - An Overview. International Journal of Phytotherapy 2015; 5(1): 48-56.

[13]. Al-Snafi AE. The pharmacology of Bacopa monniera. A review. International Journal of Pharma Sciences and Research 2013; 4(12): 154-159.

[14]. Al-Snafi AE. The Pharmacological importance of Bauhinia variegata. A Review. International Journal of Pharma Sciences and Research 2013; 4(12): 160-164.

[15]. Al-Snafi AE. The Pharmacological importance of Bellis perennis - A review. International Journal of Phytotherapy 2015; 5(2): 63-69.

[16]. Al-Snafi AE. The Pharmacological Importance of Benincasa hispida. A review. Int Journal of Pharma Sciences and Research 2013; 4(12): 165-170.

[17]. Al-Snafi AE. Chemical constituents and pharmacological importance of Bidens tripartitus - A review. Ind J of Pharm Sci \& Res 2015; 5(4): 257-263.

[18]. Al-Snafi AE. The pharmacological importance of Brassica nigra and Brassica rapa grown in Iraq. $\mathbf{J}$ of Pharm Biology 2015; 5(4): 240-253.

[19]. Al-Snafi AE. The Chemical constituents and pharmacological effects of Bryophyllum calycinum. A review. Journal of Pharma Sciences and Research 2013; 4(12): 171-176.

[20]. Al-Snafi AE. Pharmacology and medicinal properties of Caesalpinia crista - An overview. International Journal of Pharmacy 2015; 5(2): 71-83.

[21]. Al-Snafi AE. The chemical constituents and pharmacological effects of Calendula officinalis - A review. Indian Journal of Pharmaceutical Science \& Research 2015; 5(3): 172-185.

[22]. Al-Snafi AE. The constituents and pharmacological properties of Calotropis procera - An Overview. International Journal of Pharmacy Review \& Research 2015; 5(3): 259-275.

[23]. Al-Snafi AE. Bioactive components and pharmacological effects of Canna indica- An Overview. International Journal of Pharmacology and toxicology 2015; 5(2):71-75.

[24]. Al-Snafi AE. The pharmacological importance of Capsicum species (Capsicum annuum and Capsicum frutescens) grown in Iraq. Journal of Pharmaceutical Biology 2015; 5(3): 124-142. 
[25]. Al-Snafi AE. The chemical constituents and pharmacological importance of Carthamus tinctorius - An overview. Journal of Pharmaceutical Biology 2015; 5(3): 143-166.

[26]. Al-Snafi AE. The chemical constituents and pharmacological effects of Carum carvi - A review. Indian Journal of Pharmaceutical Science and Research 2015; 5(2): 72-82.

[27]. Al-Snafi AE. The pharmacological importance of Casuarina equisetifolia - An Overview. International Journal of Pharmacological Screening Methods 2015; 5(1): 4-9.

[28]. Al-Snafi AE. Clinically tested medicinal plant: A review (Part 1). SMU Medical Journal 2016; 3(1): 99 128.

[29]. Gill NS, Kaur S, Arora R and Bail M. Screening of antioxidant and antiulcer potential of Citrullus colocynthis methanolic seed extract. Research Journal of Phytochemistry 2011;5(2): 98-106.

[30]. Ali Esmail Al-snafi. Chemical constituents and pharmacological effects of Citrullus colocynthis - A review. IOSR Journal of Pharmacy 2016; 6(3): 57-67.

[31]. Nagaraju B, Anand SC, Ahmed N, Chandra JN, Ahmed F and Padmavathi GV. Antiulcer activity of aqueous extract of Citrus medica Linn. fruit against ethanol-induced ulcer in rats. Advances in Biological Research 2012; 6 (1): 24-29.

[32]. Rai SS, Banik A, Singh A and Singh M. Evaluation of anti-ulcer activity of aqueous and ethanolic extract of whole plant of Clitoria ternatea in albino Wistar rats. International Journal of Pharmaceutical Sciences and Drug Research 2015; 7(1): 33-39.

[33]. Ali Esmail Al-Snafi. Pharmacological importance of Clitoria ternatea - A review IOSR Journal of Pharmacy 2016; 6(3): 68-83.

[34]. Abdallah IZA, Khattab HAH and Heeba GH. Gastroprotective effect of Cordia myxa L. fruit extract against indomethacin-induced gastric ulceration in rats. Life Science Journal 2011; 8(3): 433-445.

[35]. Al-Snafi AE. The Pharmacological and therapeutic importance of Cordia myxa- A review. IOSR Journal of Pharmacy 2016; 6(6): 47-57.

[36]. Al-Mofleh IA, Alhaider AA, Mossa JS, Al-Sohaibani MO, Rafatullah S and Qureshi S. Protection of gastric mucosal damage by Coriandrum sativum L. pretreatment in Wistar albino rats. Environ Toxicol Pharmacol 2006; 22(1): 64-69.

[37]. Zaidi SF, Muhammad JS, Shahryar S, Usmanghani K, Gilani AH, Jafri W and Sugiyama T. Antiinflammatory and cytoprotective effects of selected Pakistani medicinal plants in Helicobacter pyloriinfected gastric epithelial cells. J Ethnopharmacol 2012; 141(1): 403-410.

[38]. Al-Mofleh LA, Alhaider AA and Mossa JS. Antigastric ulcer studies on 'saffron' Crocus sativus L. in rats. Pakistan Journal of Biological Sciences 2006; 9 (6): 1009-1013.

[39]. Halataei BA, Khosravi M, Arbabian S, Sahraei H, Golmanesh L, Zardooz H, Jalili C and Ghoshooni H. Saffron (Crocus sativus) aqueous extract and its constituent crocin reduces stress-induced anorexia in mice. Phytother Res 2011; 25(12): 1833-1838.

[40]. Bathaie SZ, Miri H, Mohagheghi MA, Mokhtari-Dizaji M, Shahbazfar AA and Hasanzadeh H. Saffron aqueous extract inhibits the chemically-induced gastric cancer progression in the Wistar albino rat. Iran J Basic Med Sci 2013; 16(1): 27-38.

[41]. Vasudevan K, Vembar S, Veeraraghavan K and Haranath PS. Influence of intragastric perfusion of aqueous spice extracts on acid secretion in anesthetized albino rats. Indian J Gastroenterol 2000; 19(2): 53-56.

[42]. Al-Snafi AE. The pharmacological activities of Cuminum cyminum - A review. IOSR Journal of Pharmacy 2016; 6(6): 46-65.

[43]. Pratyusha AC, Manmohan B, Raju S, Bhanuprasad T, Sruthi VV and Kishore RN. Comparative study of anti ulcer activity of aqueous extracts of leaves of Piper betel Linn and dried fruits of Cuminum cyminum Linn and their combination in rats. International Journal of Advanced Research 2013; 1(4): 192-195.

[44]. Dhoke V, Mishra A, Vohra R, Ghosh R and Kadam VJ. Pharmacological evaluation for anti-ulcer effect of Cynodon dactylon Pers against gastric ulcers in rats. Indian J Pharmacol 2008; 40(2): S69.

[45]. Ramesh H. Preclinical evaluation of protective effect of Cynodon dactylon Pers on experimentally induced gastric mucosal damage. Journal of Medical and Health Sciences 2013; 2(3): 89-93.

[46]. Babu KS, Shaker IA, Kumaraswamy D, Saleembasha S and Sailaja I. Indigenous effect of Cynodon dactylon in experimental induced ulcers and gastric secretions. Int Res J Pharm 2012; 3(5):301-304.

[47]. Patil MB, Jalalpure SS, Prakash SS and Kokate CK. Antiulcer properties of alcoholic extract of Cynodon dactylon in Rats. International Society for Horticultural Science 2005; dio10.17660/actahortic.680.16.

[48]. Ahmad M, Rookh M, Rehman AB, Muhammad N, Amber, Younus M and Wazir A. Assessment of antiinflammatory, anti-ulcer and neuro-pharmacological activities of Cyperus rotundus Linn. Pak J Pharm Sci 2014; 27(6-Special): 2241-2246. 
[49]. Guldur ME, Ozgonul A, Kilic IH, Sogut O, Ozaslan M, Bitiren M, Yalcin M and Musa D. Gastroprotective effect of Cyperus rotundus extract against gastric mucosal injury induced by ischemic and reperfusion in rats. Int J Pharmacology 2010; 6(2): 104-110.

[50]. Zhu M, Luk HH, Fung HS and Luk CT. Cytoprotective effects of Cyperus rotundus against ethanol induced gastric ulceration in rats. Phytother Res 1997; 11(5): 392-394.

[51]. Thomas D, Govindhan S, Baiju EC, Padmavathi G, Kunnumakkara AB and Padikkala J. Cyperus rotundus L. prevents non-steroidal anti-inflammatory drug-induced gastric mucosal damage by inhibiting oxidative stress. J Basic Clin Physiol Pharmacol 2015; 26(5): 485-490.

[52]. Dalal K, Singhroha S, Ahlawat S and Patra A. Antidiarrhoeal activity of roots of Cicer arietinum Linn. International Journal of Research in Pharmaceutical and Biomedical Sciences 2011; 2(1): 268-270.

[53]. Attia HA. and Samar MM, 2004. Antidiarrhoeal activity of some Egyptian medicinal plant extracts. Journal of Ethnopharmacology 2004; 92(2-3): 303-309.

[54]. Al-Snafi AE. The chemical constituents and pharmacological effects of Convolvulus arvensis and Convolvulus scammonia- A review. IOSR Journal of Pharmacy 2016; 6(6): 64-75.

[55]. Al-Bowait MEA. Immunotoxicity of Convolvulus arvensis (Binweed) in sheep and rats. PhD thesis, Sudan University of Science and Technology, College of Animal Production Science and Technology 2007.

[56]. Medical jurisprudence and toxicology, Scammony, https://archive.org/stream/ Medical JurisprudenceAndToxicology/TXT/00000604.txt

[57]. Gurjar Phytochem Pvt. Ltd. Scammony Resin 60-70 http://www.gurjarphytochem. com/scammony-resinmanufacturer/

[58]. Jabeen Q, Bashir S, Lyoussi B and Gilani AH. Coriander fruit exhibits gut modulatory, blood pressure lowering and diuretic activities. J Ethnopharmacol 2009;122(1):123-130.

[59]. Ramya LB, Mohan LS and Sharavana KA. Evaluation of antidiarrheal activity of methanolic extract of Crotalaria juncea Linn in albino Wistar rats. International Journal of Preclinical Research 2011; 2(2):66-70.

[60]. Al-Snafi AE. The contents and pharmacology of Crotalaria juncea- A review. IOSR Journal of Pharmacy 2016; 6(6): 77-86.

[61]. Sahoo HB, Sahoo SK, Sarangi SP, Sagar R and Kori ML. Anti-diarrhoeal investigation from aqueous extract of Cuminum cyminum Linn seed in albino rats. Pharmacognosy Res 2014; 6(3):204-209.

[62]. Janbaz KH, Shabbir A, Mehmoo MH and Gilani AH. Insight into mechanism underling the medicinal use of Cydonia oblonga in gut and airways disorders. The Journal of Animal \& Plant Sciences 2013; 23(1): 330-336.

[63]. Minaiyan M, Ghannadi A, Etemad M and Mahzouni P. A study of the effects of Cydonia oblonga Miller (Quince) on TNBS-induced ulcerative colitis in rats. Res Pharm Sci 2012; 7(2): 103-110.

[64]. Romero MA, Dávalos HN and Astudillo-Vázquez A. Activated gastrointestinal del fruto de Cydonia oblonga Miller. Rev Latinoamer Quím 2009; 37(2):115-121.

[65]. Babu DSR, Neeharika V, Pallavi V and Reddy MB. Antidiarrheal activity of Cynodon dactylon. Pers. Pharmacognosy Magazine 2009; 5(19): 23-27.

[66]. Al-Snafi AE. Chemical constituents and pharmacological effects of Cynodon dactylon- A review. IOSR Journal of Pharmacy 2016; 6(7): 17-31.

[67]. Al-Snafi AE. A review on Cyperus rotundus A potential medicinal plant. IOSR Journal of Pharmacy 2016; 6(7): 32-48.

[68]. Shamkuwar PB, Hoshamani AH and Indrajeet D. Antispasmodic effect of Cyperus rotundus L (Cyperaceae) in diarrhoea. Der Pharm Lettre 2012; 4: 522-224.

[69]. Uddin SJ, Mondal K, Shilpi JA and Rahman MT. Antidiarrhoeal activity of Cyperus rotundus. Fitoterapia 2006; 77(2): 134-136.

[70]. Daswani PG, Brijesh S, Tetali P and Birdi TJ. Studies on the activity of Cyperus rotundus Linn. tubers against infectious diarrhea. Indian J Pharmacol 2011; 43: 340-344.

[71]. Daswani PG, Birdi TJ and Antia NH. Study of action of Cyperus rotundus root decoction on the adherence and enterotoxin production of diarrhoeagenic Escherichia coli. Indian Journal of Pharmacology 2001; 33: 116-117. 